\title{
Was Karl Marx an Ecosocialist?
}

\author{
Carl Boggs
}

Facing the provocative question as to whether Karl Marx could be regarded as an ecosocialist - the very first ecosocialist - contemporary environmentalists might be excused for feeling puzzled. After all, the theory (a historic merger of socialism and ecology) did not enter Western political discourse until the late 1970s and early 1980s, when leading figures of the European Greens (Rudolf Bahro, Rainer Trampert, Thomas Ebermann) were laying the foundations of a "red-green" politics. That would be roughly one century after Marx completed his final work. Later ecological thinkers would further refine (and redefine) the outlook, among them Barry Commoner, James O'Connor, Murray Bookchin, Andre Gorz, and Joel Kovel. It would not be until the late 1990s and into the new century, however, that leftists around the journal Monthly Review (notably Paul Burkett, John Bellamy Foster, Fred Magdoff) would begin to formulate the living image of an "ecological Marx." The most recent, perhaps most ambitious, of these projects is Kohei Saito's Karl Marx's Ecosocialism, an effort to reconstruct Marx's thought from the vantage point of the current ecological crisis.

Was the great Marx, who died in 1883, indeed something of an ecological radical - a theorist for whom, as Saito argues, natural relations were fundamental to understanding capitalist development? Saito's aim was to arrive at a new reading of Marx's writings based on previously unpublished "scientific notebooks" written toward the end of Marx's life. From this and related materials, Saito concludes that familiar views of Marx's productivism and Promethean attitude toward nature are misplaced. These myths should give way to a more enlightened view of Marx derived from a broader appreciation of his work. It follows, moreover, that classical Marxism as a whole deserves extensive re-reading, consistent with an ecological turn beginning in the late 1860s.

Could Saito's rather careful exploration of Marx's writings represent a major step toward retrieving the long-obscured contributions of an ecological theorist -- an ecosocialist? Equally worth asking, did the theoretical paradigm fashioned by Marx and collaborator Friedrich Engels manage to advance the kind of scientific materialism (said to be congruent with an ecological outlook) that would later be associated with the Monthly Review authors? The present essay sets out to critically address these and related questions.

If Marx and Engels were indeed the first ecosocialists of record, that achievement - whatever its scientific imprimatur - would have been miraculous given the generally limited interest in matters environmental during the nineteenth century. Such intellectual pursuits would have encountered serious barriers, not least being a Zeitgeist of almost religious faith in Enlightenment values of maximum economic and technological growth, especially in the European context. They would need to have been extraordinarily prescient. Ecosocialism, even today, is among the more peripheral tendencies, addressing deep origins of the modern crisis while avoiding earlier (productivist, statist) traditions aligned with Communism and social democracy. As Michael Lowy writes, such politics "aims not only to transform the relations of production, the productive apparatus, and the dominant consumption patterns but to create a new way of life, breaking with 
the foundations of the modern Western capitalist/industrial civilization." Lowy himself was rather skeptical that the Marxist classics were adequate to this task.

Failure to reverse the crisis will, in Lowy's view, leave the planet open to imminent descent into catastrophe. "In sum", he argues, "the capitalist world system is historically bankrupt. It has become an empire unable to adapt, whose very gigantism exposes its underlying weakness. It is, in the language of ecology, profoundly unsustainable and must be changed fundamentally, nay replaced, if there is to be a future worth living." 2 This same point was more recently, and more vigorously, set forth by David Wallace-Wells, in The Uninhabitable Earth, where he suggests that managers of the industrial world are presently on a "kamikaze mission" of endless material growth. ${ }^{3}$

Obsessive growth ensures not only a worsening crisis but, in all probability, irreversible planetary collapse. Wallace-Wells, among more recent critics, has sounded the alarm: "In that world ... the oceans would eventually swell two hundred feet higher, flooding what are now twothirds of the world's major cities; hardly any land on the planet would be capable of efficiently producing any of the food we now eat . . . probably about a third of the planet would be made unlivable by direct heat; and what are today literally unprecedented and unlivable droughts and heat waves would be the quotidian condition of whatever human life was able to endure." Writing in Fossil Capital, Andreas Malm comments: "The point of too late is coming closer by the day ... The tradition of the dead is breathing down the necks of the living, leaving them with two choices: smash their way out of business-as-usual . . . or succumb to an accumulated, unbearable destiny." ${ }^{5}$ A pressing issue we confront here is whether nineteenth-century Marxism, however theoretically refurbished, can be enlisted for purposes of overcoming the crisis.

\section{In Search of an Ecological Marx}

Saito's book has been widely heralded as something of a theoretical breakthrough in the study of Marxist classics, having won the esteemed Isaac Deutscher Memorial Prize in 2017. Kevin Anderson describes Karl Marx's Ecosocialism (on the back cover) as "a new interpretation of Marx, one that is timely given the economic and ecological crises of contemporary capitalism." For his grand efforts, Saito relies heavily not only on Marx's early writings but on previously unpublished materials, including many entries of his "scientific notebooks" where, nearing the 1870s, Marx fixed increasing attention on the natural sciences.

After the meticulous study of these materials, Saito concludes that ecology must now be seen as not merely important but central to Marx's theoretical interests as he navigated beyond the more important writings spanning the 1840 s to $1860 \mathrm{~s}$. This interpretation clashes with the prevailing view of Marx based on the Communist Manifesto and other sources, where he assumed "unlimited economic and technological developments as a natural law of history and propagated the absolute mastery of nature, both of which run counter to any serious theoretical and practical consideration of ecological issues such as the scarcity of natural resources and the overloading of ecospheres." The well-known emphasis in Marx and Engels on human domination of the natural world - a common motif of the period - is now said to require rethinking that more fully takes into account Marx's later writings. Critics have been mistaken in the belief that Marx and Engels ignored the environmentally destructive force of modern industry, a system that was beginning to move toward limitless material production and mass consumption. Lowy is one modern ecosocialist who argues that Marx did not adequately consider how capitalism would become so ceaselessly destructive of the natural habitat.

Saito writes that since Marx's most important work, Capital, remained incomplete, the later notebook materials must be assigned special value. Roughly half of these entries dealt with several natural sciences - biology, chemistry, botany, geology - yet "the importance of this work remained neglected for more than a century." Appreciation of these materials, along with such familiar earlier works as the 1844 Economic and Philosophical Manuscripts, now "allows 
scholars to see Marx's ecology as a fundamental part of his critique of political economy."' In other words, we have now reached a point where ecological problems must be understood as integral to the classical Marxist enterprise.

Saito's undertaking aims for no less than a systematic reconstruction of Marx's critique of capitalism focused on a rupturing of the organic bond between humans and nature, between society and the natural environment. Thus: “. . . Marx consistently bestowed a central role in his critique of modern society to the problem of separation of humans from the earth"10 - a problem already identified in the 1844 Manuscripts. During the 1870s, in particular, Marx came to see that "metabolic rifts [between society and nature] were the most serious problem of capitalism."11 The notion of "metabolic rift" had been previously explored by such writers as Foster, but here Saito renders it a centerpiece of Marxian analysis. Alongside the degradation of labor, capitalism gave rise to a "historical deformation" of nature - the two processes convergent, part of the same dialectic.

As capitalism disturbs the "natural metabolism," according to Saito, "the capitalist tendency to degrade nature is derived from the law of commodity exchange" - though the precise ways that "law" winds up impacting the natural habitat is never fully explained. ${ }^{12}$ Saito argues that Marx never abandoned his 1844 affirmation of the "absolute unity of humans and nature", which he proceeded to refine in his later work (including the notebooks), where he investigated such topics as soil depletion and climate change. While capitalism destroyed that (imputed) organic unity, it would presumably be the historic task of socialism to restore a dynamic, sustainable metabolic process. Human mastery of nature would come to an end, ultimately replaced by the integration of the two realms. To fully comprehend this phenomenon, the theory would require a more rigorous materialist foundation: "An analysis of Marx's project needs to go beyond the earlier interpretation and include the analysis of the material world as a central object of the study." "13

For Saito, as for Marx, labor within the capitalist economy is a purposeful, conscious activity where humans mediate, regulate, and control (or seek to control) the metabolism between their own self-activity and the rhythms of nature - though here again the constituent elements of nature (addressed later) are never clearly elaborated. Where nature is fetishized, as is so often the case with Marx, it is also left rather amorphous, undifferentiated. Under capitalism, the developmental process is intercepted by an enduring "rift" associated with multifaceted environmental challenges. In Saito's reading, Marx was well ahead of his time, anticipating ecological crises that would eventually accompany the more familiar economic contradictions. If true, this would suggest an overturning of Marx's supposed Prometheanism, according to which sustained industrial and technological expansion would continue into the new socialist order. Saito writes: "Only a systematic analysis of Marx's theory of metabolism as an integral part of his critique of political economy can convincingly demonstrate, against the critics of his ecology, how the capitalist mode of production brings about various types of ecological problems due to its insatiable desire for capital accumulation." 14

Beyond calling attention to the likelihood that Marx brought a discourse of environmental ethics into his work, Saito argues for its centrality: "In spite of its unfinished state, Marx's political economy allows us to understand the ecological crisis as a contradiction of capitalism." 15 Just how Marx and Engels - or any other theorists of the period - might have defined "ecological crisis" remains unclear. Saito insists that the problem of ecology was never of secondary or peripheral interest to Marx, that in fact, "metabolic rifts were the most serious problem of capitalism."16 Beyond that, modern theoretical approaches to ecology owe a great debt to Marx's deep insights into commodity production, labor, and the endemic conflict between humans and nature.

If Marx's philosophy in his earliest writings transcended the antinomies of traditional materialism and German idealism - reaching a dialectical synthesis of the two - in Saito's view, Marx turned increasingly toward scientific materialism from the late 1860s onward, consistent with his sharpening fixation on ecology. His notebooks during those years reveal keen attention to 
several natural-science disciplines, as noted. The very idea of "metabolic rift" affirms a profoundly scientific, if not ecological, preoccupation. Here we see glimpses of Marx's interest in further exploring the tensions between capital and nature, between the economy and its surrounding landscape. After 1868, according to Saito, "Marx [in contrast to his earlier writings] came to clearly recognize natural limits as such, parting from a myth of unlimited technologically-driven increase in production." ${ }^{17}$ Hardly Promethean, the Marx of Saito's reconstruction nearly comes across as a contemporary deep ecologist wedded to "limits of growth."

Despite his thorough probing of Marx's work, Saito is hardly the first interpreter of an "ecological Marx," or even the first to call attention to the idea of "metabolic rift." That distinction would be claimed by Foster, who, in Marx's Ecology (2000), set forth arguments prefiguring those of Saito and approximating those of colleague Burkett in Marx and Nature (1999). ${ }^{18}$ Later volumes - for example, Creating an Ecological Society (2017) by Magdoff and Chris Williams - have further sought to "ecologize" the Marxist tradition. ${ }^{19}$ Saito's departure from earlier treatments thus appears considerably less radical than the boosters have wanted us to believe. Saito's main contribution here lies in the emphasis he places on Marx's post-1868 work. All conclude that the long-accepted Marxist domination-of-nature motif has been finally and thoroughly debunked.

As for the concept of "metabolic rift," that already figured centrally in Foster's account, as did the emphasis on rigorous scientific materialism seen as indispensable to ecological thought. Foster likewise calls attention to a post-1860s shift toward Marx's heightened understanding of how capitalism degrades nature. In Foster's words: "In their later writings, significantly, Marx and Engels were to make the consideration of such ecological contradictions a central part of their critique of modern civilization (and particularly capitalist society)." 20 Renewed attention to the natural sciences was said to further solidify this far-reaching theoretical shift.

Foster stresses Marx's preoccupation with the "necessary unity of human and natural existence" that had appeared in the 1844 Manuscripts. ${ }^{21}$ The same capitalist mechanisms that gave rise to alienated labor simultaneously produced the alienation of humans from nature. All of this, in Foster's view, could be analyzed through the lens of dialectical materialism or scientific naturalism, which was thought to have broadened the panorama of natural relations. Foster goes to great lengths to distinguish Marx's dialectical approach from earlier forms of crude, onedimensional materialism - though, as we shall see, with at best only partial success. The crucial point here is that an "ecological Marx" would presumably have to rest on firm scientific mooring. That claim would be validated, in Foster as in Saito, with reference to the elevated focus of both Marx and Engels on natural sciences in their later years.

The seductive idea of an "ecological Marx" has been articulated, in rather different ways, across the literature explored here. There remains the question of just how central an ecological outlook might have been to the overall work of Marx and Engels. Were identifiable ecological contradictions basic to the process of capital accumulation - or could they have been more incidental? Despite several volumes of work on this topic, much of it centered around the journal Monthly Review, there is little certainty and indeed much disagreement. Foster, for example, adopts a rather extreme position: "I finally came to the conclusion that Marx's worldview was deeply and indeed systematically ecological ... and that this ecological perspective derived from his materialism." 22 Along similar lines, Saito contends that Marxist theory today cannot be grasped in the absence of its ecological dimension, that it was fundamental to his critique of capitalism. ${ }^{23}$ Further: "In spite of its unfinished state, Marx's political economy allows us to understand the ecological crisis as a contradiction of capitalism." 24

Elsewhere in Saito, however, we encounter something of a minimalist view: "We see 'hints' in his unpublished writings that indicate his intention to explicate various tensions between capital and nature." 25 Hints? Intention? Tensions? Such language scarcely calls forth a powerful ecological dynamic in Marx, earlier or later. In fact, this very discursive minimalism offers clues to theoretical problems ahead.Equally pressing questions arise as we scrutinize the general work of Marx and Engels. Marx's well-known emphasis on human-nature unity in the 1844 
Manuscripts turns out to be countered by strongly productivist passages in such works as the Manifesto, Grundrisse, and Capital - revealing passages that should not be downplayed. Insofar as Marx and Engels are considered to have become more deeply ecological throughout the 1870s, their later writings (aside from the unpublished notebooks) could turn out to be even more revealing.

\section{| Capitalism and the Natural World}

What possible meaning can we derive from the emergence of an "ecological Marx" that might be relevant to the twentieth century and beyond? Did the larger thrust of classical Marxist writings actually furnish the sort of ecological outlook so tenaciously championed by Foster and Saito? Did the later, presumably more mature, contributions of Marx and Engels - writings with a decidedly natural-science preoccupation - alter the balance, finally driving the theory away from its earlier Promethean impulses? With all the attention some classical Marxist texts are said to have devoted to philosophical materialism, do we encounter signs in the later work of serious ecological analysis?

At the outset, Marx's own early attention to human-nature relations in the 1844 Manuscripts - a point of emphasis in Saito - while salient, scarcely rises above the level of abstract generalities. One finds relatively little substance on either side of this equation, less specificity yet when addressing the historical dimensions. Many passages reflect little more than truisms, starting with the premise that humans are part of the natural world, which they self-consciously transform by means of their labor. Thus in the Manuscripts Marx famously writes: "Man lives on nature - means that nature is his body, with which he must remain in continuous intercourse if he is not to die, that man's physical and spiritual life is linked to nature means simply that nature is linked to itself, for man is part of nature." ${ }^{26}$ (All masculine references are re tained throughout, consistent with Marx's own usage.) However, profound Marx's statements here might appear, they are framed at such levels of generality as to be emptied of historical or political meaning; they could align with the most harshly instrumental approaches to nature. Marx goes on to say that "Conscious life-activity directly distinguishes man from animal life-activity", 27 another truism that, in this case, ultimately feeds into Promethean assumptions. Throughout these pages, and later, Marx places overwhelming emphasis on human self-activity in the historical process of struggling against external barriers, that is, overcoming both personal and collective estrangement.

At many points throughout his most theoretically insightful texts, Marx stressed the liberating potential of productive forces - first within capitalism, then given fuller and more rational expression with the historical achievement of socialism. Questions regarding harm from economic and technological (also urban) colonization of the natural world would be rare. One finds little insight into how sustained material development might surpass natural limits or degrade the natural landscape. On the contrary, his prevailing attitude seemed consistent with that of an enlarged (presumably more enlightened) mastery of nature. In one familiar passage from the Manifesto, after praising the bourgeoisie for creating "colossal production forces," Marx and Engels write: "Subjection of Nature's forces to man, machinery application of chemistry to industry and agriculture, steam-navigation, railways, electric telegraphs, clearing of whole continents for cultivation, canalization of rivers, whole populations conjured out of the ground what earlier century had even a presentment that such productive forces slumbered in the lap of social labor?" 28 Elsewhere in the Manifesto, they enthuse over how the proletariat, once having conquered power, will wrest "all capital from the bourgeoisie, to centralize all instruments of production in the hands of the State ... and to increase the total productive forces as rapidly as possible." ${ }^{29}$

This more or less unfettered productivism found its parallels in both The Grundrisse and the first volume of Capital, not to mention later works (a point taken up later). In The Grundrisse, 
Marx writes: "Nature builds no machines, no locomotives, railways, electric telegraphs, selfacting mules, etc. These are products of human industry; natural material transformed into organs of the human will over nature, or of human participation in nature. They are organs of the human brain, created by the human hand; the power of knowledge, objectified." 30 Such passages are repeated throughout the work of both Marx and Engels, virtually from beginning to end, reflecting an identifiable intellectual persuasion. Another example, from Capital (volume one): “Animals and plants, which we are accustomed to considering as products of, say last year's labor, but the result of a gradual transformation, continued through many generations, under man's superintendence, and by means of his labor." 31 Where might one locate a clearer statement of the Promethean vision?

In Capital (volume three), a work of detailed economic analysis, Marx writes: "Freedom . . . can only consist in socialized man, the associated producers, rationally regulating their interchange with Nature, bringing it under their common control instead of being ruled by it as by the blind forces of Nature, and achieving this with the least expenditure of energy and under conditions most favorable to, and worthy of, their human nature." 32 Here, as elsewhere, the "blind forces" of nature are to be tamed and mastered by rational forces of modern production, reinforced by the great achievements of modern science and technology. This same motif is carried forward in Critique of the Gotha Program, at presumably the height of Marx's ecological turn (in 1875). He writes: "And insofar as man from the beginning behaves toward nature, the primary source of all instruments and subjects of labor, as an owner, treats her as belonging to him, his labor becomes the source of use values, therefore also of wealth." 33

Even more problematic for champions of an "ecological Marx" is a number of generalizations in the publication of Engels' Anti-Duhring, which appeared toward the end of Marx's ostensible ecological turn. This work of a rigid materialist epistemology, first published in 1878, was read and approved by Marx, who also wrote an introduction to the section titled "Socialism: Utopian and Scientific." Engels had arranged three general chapters of Anti-Duhring as a pamphlet on the origins of Marxism, outlining its general approach to history. Originally published in French in 1880 (just three years before Marx's death), this section appeared in many languages and became - along with the Manifesto - surely the most influential presentation of Marxist theory for the late nineteenth century and beyond. An English translation appeared in 1892.

As with the Manifesto, this text celebrates the stupendous growth and concentration of capitalist economic power, with its unprecedented dominion over society and nature - the trajectory of a new society. The great "expansive force of modern industry" was expected to open up wonderful new vistas of revolutionary change. ${ }^{34}$ Overcoming the forces of anarchy, dispersion, and resistance, this behemoth was a source of "an unbroken, constantly accelerated development of productive forces and therefore for a practically unlimited increase in production itself." 35 Humans now "for the first time, become the real, conscious lord of nature, because [they] have now become master of [their] own social organization." 36 For an essentially sanctified work of classical Marxism first circulating in the 1890s, it would be difficult to find a bolder affirmation of the human mission to control and exploit nature. With European intellectual attraction to Marxist ideas seemingly at its peak, could readers have been troubled by any confusion between early "philosophical" Marxism and later "scientific" Marxism?

Engels continues forcefully along these lines: "By this act - seizing power - the proletariat forces the means of production from the character of capital . . . and gives their socialized character complete freedom to work itself out." ${ }^{37}$ And: "Man, at last the master of his own form of organization, become at the same time the lord over nature, his own master - free." ${ }^{\prime 3}$ Here all ambiguity has been stripped from one of the most important classical Marxist texts. In the end, for both Marx and Engels such human capacity to simultaneously remake society and the natural world would be magnified by the historic spread of "scientific socialism" - and would be clearly understood as such by inheritors of the orthodoxy, starting with Karl Kautsky, Georgi Plekhanov, and a circle of "legal Marxists" in Russia.

Beyond Marx, Engels had sought to build a general (materialist) philosophy on a foundation 
of natural sciences - a task he further pursued in Dialectics of Nature, which in fact departed little from the more systematic work of Anti-Duhring. One problem is that Dialectics was both rudimentary and fragmentary, whatever the author's grand ambitions for it - a volume never completed and indeed never published until 1925. (Engels worked on the manuscript sporadically between 1872 and 1882, at a time of Marx's own stepped-up interest in the physical sciences.) In this work, Engels construed science as a dialectical process of interconnections leading to qualitative change, though precisely in what ways historical change would replicate or be driven by the physical change was suggested but never elaborated. This was surely the most "scientific" or "materialist" of classical Marxist writings. The point is not to judge this work in terms of its epistemology or even its political relevance, but rather to emphasize its congruence with the Promethean impulse. Hardly surprising, there is nothing in this widely-read text to contradict above-cited passages from Anti-Duhring or other earlier Marxist sources.

Marx's own attention to the natural sciences toward the end of his life, along with what nowadays might be labeled "ecological" discourses, is not in doubt - yet neither is his agreement with those passages from Anti-Duhring cited above. Returning to Saito, the claims turn out to be substantially more, that indeed Marx had become a systematic ecological thinker, far ahead of his time and not to be confused with the rather commonplace Prometheanism, or Enlightenment rationality, of his time. Saito argues that "Marx developed his ecological thought as a critique of capitalism," adding: "A more complete investigation of new material published by MEGA showed that a stereotypical (and false) critique of his indifference to the scarcity of natural resources and the burdening of our ecospheres, and another critique of his Promethean superstition on limitless economic and technological development, are not tenable." 39

Saito also points out that "Marx consistently bestowed a central role in his critique of modern society to the problem of the 'separation' of humans from the earth." ${ }^{\text {" }}$ More precisely: "In contrast to a widespread critique that Marx is a blind supporter of absolute domination over nature, his vision of the future society demands a careful and sustainable interaction with nature, based on a distinct recognition of its limits." ${ }^{41}$ In contrast to the destructive logic of capitalism, a more rational (socialist) form of material production would be congruent with an ecologicallysustainable mode of development.

Reading Saito - in alignment with both Marx and Engels - it is difficult to avoid some inescapable problems. First, while references to unified human-nature relations appear valid enough, they remain frustratingly abstract, even tautological. Much the same can be said regarding the "metabolic rift" between society and nature -- a conflict simply rooted in the logic of advancing industrialization in any setting. Such generalizations lack both historical and ecological concreteness, suggesting little that might inspire critical analysis. The interaction between humans and nature, mediated by labor, was for Marx important to his overall theory but was never given the specificity that shaped his deeper treatment of political economy. If we learn that humans, through continuous life-activity, transform the natural world, such truth is hardly enlightening.

More troublesome yet is how the very concept "nature" is framed in the writings of Marx and Engels. It is simultaneously vague, weakly-defined, and incomplete - a criticism more fully discussed in the next section. However, often the reference is invoked across many pages of work, the concept ultimately reveals little and, in fact, obscures a great deal. Moreover, the passages (cited above) that affirm in clearest terms human mastery of nature, while illuminating, actually embrace a standard ideological trope of the period, consistent with an uncompromising faith in supreme industrial and technological growth. In this context, even the most extreme worship of nature - much like the idealization of "human nature" - winds up signifying little.

Third, numerous passages cited in Engels' Anti-Duhring (again, fully endorsed by Marx) run directly and systematically counter to Saito's reading of the later Marx - even accepting the validity of Marx's "ecological turn" after 1868. We can observe here, with abundant clarity, how Marx and Engels shared an ethos of productivism right to the very end of their prolific careers. Given the stage of European capitalist development in the 1870s and 1880s, not to mention the 
well-known positivist ascendancy of the period, this reckoning is not very shocking. Saito's claim that Marx's Promethean impulse has been resolutely debunked is not very convincing when measured against these and kindred passages. It is worth noting, moreover, that the motif of limited growth (assuming finite resources) is never seriously taken up in the vast contributions of Marx and Engels, nor indeed in the work of their immediate successors (Kautsky, Plekhanov, and V. I. Lenin among them). ${ }^{42}$

At the same time, Marx's laudable interest in the natural sciences toward the end of his life does not in itself reflect an ecological sensibility - any more than we can automatically derive such views from the work of contemporary physicists or chemists, many of whom do military research. Obviously, Marx's own ability to make contributions in these fields had to be severely limited, whatever his degree of interest. Further, attempts to extrapolate theoretical methods or political substance from the study of natural sciences for purposes of historical analysis were, then as now, not likely to be promising. The knowledge accumulated in those fields of study, moreover, has never been innately progressive, much less ecological.

More crucially, as we begin to examine the modern fortresses of wealth and power, the very actuality of human mastery of nature is virtually impossible to avoid once we take into account the vast array of forces warring against every part of the planetary ecosystem. There is no avoiding the fact that advanced industrialism spells not merely control of nature but an all-out assault on non-human life and its support systems. In fact, under any form of industrialization and urbanization, the very idea of an organic reunification of human-nature relations must be viewed as sheer delusion. The issue rather is precisely what form and what scope that domination will assume. It might be asked whether Marx and Engels ever arrived at a coherent ecological analysis of modernizing capitalism - that is, anything beyond their seminal work on (early) capitalist political economy? As Saito writes, there are surely hints here and there of Marx's interest in environmental concerns, but, as noted, these never reached levels of systematic conceptualization. Why was so little of Marx's "scientific" work after 1868 published at the time? Why did so many heirs of classical Marxism adopt even more extreme forms of scientific materialism and systemic productivism than were present in Marx's own work?

In the end, Marx turned out to be rather consistent in his belief that humans had the need (and capacity) to define, shape, and exploit the natural world. Engels pushed this motif even further. To have believed otherwise, in view of their larger theoretical enterprise, would have to seem far-fetched. Marx and Engels repeatedly insisted that the natural environment is subject to rational human intervention within a dynamic process of historical transformation, control of productive forces obviously being central to this process.

\section{What is Nature?}

The fate of the planet in an era of deepening ecological crisis might well depend, in the final judgment, on philosophical approaches to nature -- a concept often romanticized to insignificance. Nowadays, theorists of diverse outlooks extend (usually obligatory) references to it. The first problem is that the reference easily slips into vague and formless usage, subject to myriad interpretations. Theorists are inclined to endow the natural world with wondrous ethical content - that is, a uniquely noble realm vulnerable to endless threats: industrialization, urban colonization, technology, military violence, consumerism, and so forth. Nature is readily wrapped in mystical, romantic, primitive virtues menaced by debilitating modernity, above all capitalist modernity.

With advancing levels of industrialization, the search for a social order in which humans do not exert dominion over nature would be futile. The vast growth of economic, political, military, even cultural power ultimately ensures such dominion. The overturning of capitalism - the first step being the elimination of private property in the system of production - has never in itself brought a human-nature balance, witness the destructive history of Soviet and other Communist 
regimes across the twentieth century. That historical reality has never discouraged ecologists and other progressives from envisioning epic reunification of humans and nature, society, and the natural habitat in a new, more rational phase of development.

As powerful interests push the global ecosystem toward collapse, leftists of various stripes look toward a liberated order based on human rationality, ecological sanity, and sustainable development - requiring, in a word, full reunification of humans and nature. This outlook has, since the 1970s, been spearheaded by groups that might be loosely defined as "deep ecologists," advocates of biocentric ethics in which all parts (or most parts) of the natural habitat are deemed to have "inherent worth." Ecosystems develop and mature within constantly evolving, thriving, interactive communities of human and non-human life in the legacy of such theorists as Rousseau and Kropotkin. Paul Taylor refers to this approach simply as "the ethics of respect for nature." ${ }^{\prime 3}$ From this viewpoint, humans do not (or should not) exert dominion over other forms of biological life, a maxim harshly at odds with the daily imprint of modern industrial society. Change depends on the capacity of humans to discover and enlarge their historical role as moral and political agents within local, self-managed communities.

Whatever its philosophical validity, the problem here is the highly implausible rejection of modernity itself, not to mention the absence of any political strategy for getting there - a virtual celebration of anti-politics. Leaving aside the obvious flaws of such utopianism, the vision of human-nature unity has forever been shared among ecologists of diverse outlooks. We have seen how Foster, Saito, and other proponents of an "ecological Marx" engage such utopianism while identifying it with Marx and Engels, thus rejecting the implications of a Promethean Marx. As shown by passages from the 1844 Manuscripts, Marx himself seemed dedicated to historical unification of humans with nature - a prospect conceivable, however, only with the final transcendence of capitalist power and class relations.

The complex interplay of humans and nature, mediated by production and labor, did in fact, inform a good deal of Marx's work - though, as mentioned, compromised by an instrumentalism present in the Manifesto and elsewhere. As humans transform the external world, they simultaneously transform themselves within the larger ensemble of relations. With the transition to socialism, it follows, longstanding divisions separating city and countryside would presumably shrink, though this process too is never specified. In any case, based on the logic of historical development, humans would dialectically interact with nature, re-appropriating it within a process of revolutionary change.

Beyond these and other similarly general propositions, however, Marx never developed a philosophy of nature that could anticipate the work of later ecologists; his categories of analysis were much too imprecise, malleable. As Saito points out, Marx did lay out a theory of metabolic rift that might be viewed as integral to the critique of the political economy, yet it appears this too was never fully elaborated or effectively combined with the broader critique. ${ }^{44}$ Saito adds that Marx's "vision of the future society demands a careful and sustainable interaction with nature, based on a distinct recognition of its limits." "45 Yet this claim is muddied by the aforementioned productivism and instrumentalism that, as we have seen, pervades Marx's overall body of work.

Aside from a rather diffuse view of nature, Marx's theoretical limits just as critically extended to what is left out, diminished: the entire universe of nonhuman life, including other species that have long inhabited the earth, and are threatened as never before. In his dialectical treatment of (human) "species-being," integral to the transition from (human) necessity to freedom, Marx reveals a void never addressed by Saito, Foster, or other "Marx-as-ecologist" boosters. This problem becomes all the more illuminating once we consider that humans - with their deep levels of anthropocentrism and speciesism - continue to wage nonstop war against nonhuman nature, a savagery intensified under modern capitalism. At this point, the concept of "metabolic rift" so central to Saito's reading of Marx falls pathetically short of capturing an unthinkable reality; the distance between "war" and "rift" could not be wider.

For Marx, nonhuman beings simply never figured in his concept of "nature", never mattered within the ecological calculus. He refers to a "humanized nature" that reflects the "essential 
powers of man" - another tribute, it turns out, to the ethos of instrumental rationality. ${ }^{46}$ He writes: "Man makes his life-activity itself the object of his will and his consciousness. He has conscious life-activity . . . Conscious life-activity directly distinguishes man from animal life-activity. It is just because of this that he is a species-being." ${ }^{\prime 47}$ Passages like this recur throughout Marx's work, not surprising given prevailing ideological norms of the period. It is commonplace nowadays to acknowledge the sentience, or life-purpose, of members of other species, increasingly so within ecological circles. Still, while Marx and Engels might be excused for this sparse understanding of nature, that merely reaffirms the severe limits of classical Marxism as a possible cornerstone of modern ecological thought. The problem resides less in the classical theory as such than in the unpardonable failure of more recent interpreters to question and transcend those limits.

The widening critique of speciesism actually goes back several decades, well before recent efforts to promote an "ecological Marx." Of course, Marx's own work could never benefit from the contributions of an entire generation of animal-rights research and theorizing. As early as the 1940s, Theodor Adorno and Max Horkheimer in their Dialectic of Enlightenment questioned how "mankind, instead of entering into a truly human condition, [was] sinking into a new kind of barbarism." Crucial to this dystopic view was a critique of ruling interests for their ruthless pursuit of superiority over the rest of society, over nature, overall nonhuman life within it. ${ }^{48}$ For modern capitalism, animal populations were ritually subjected to unspeakable horrors - a savagery viewed as reflecting the absolute powers of human dignity and supremacy. ${ }^{49}$ In such a gruesome world, "the whole earth bears witness to the glory of man." 50 This war against nature had all the features of a planned, routinized, celebrated assault on "animal existence." 51 Written several decades ago, these passages would barely offer glimpses into a future carnage of factory farms, slaughterhouses, medical experimentation, hunting as a sport, and myriad other contemporary forms of barbarism.

No longer a submerged issue, the systematic torture and murder of billions of animals yearly is better understood as intrinsic to the entire matrix of industrial and technological society, integral to both capitalism and post-capitalism. The practices are fully normalized, embedded in the basic rhythms of daily life: corporations, government, the military, churches, health care, the food system. While critical social theory might be expected to deconstruct all institutions and practices of domination, here we have an instance of intellectual work allowing for an inexplicable moral and political exemption. The unfathomable scale of this violence against nature far exceeds anything encompassed by the notion of "metabolic rift." Does such a "rift" ever apply to other species? On this point, John Sanbonmatsu is prompted to ask: "When atrocity becomes the very basis of society, does society not forfeit its right to call itself moral?" ${ }_{2}$ Unfortunately, Marxism, in its different variants, has lent its credibility to this particularly savage "domination of nature." Here the all-too-familiar fetishism of Nature turns into the ugliest of fictions.

Sanbonmatsu argues that this global system of institutionalized brutality is simultaneously a "mode of production itself," profiting scandalously from animal goods, services, and resources - a sector of the political economy ignored only by dint of fierce determination. ${ }^{53}$ Over the past decades, it has indeed become a mode of production (and consumption) without equal. Speciesism thus amounts to far more than an ideology: it fits squarely within an ensemble of relations, fundamental to the self-activity of humans in pursuit of their privileged "species-being." All the cherished signifiers of human "progress" - science, technology, industry, medicine, education - are routinely employed to advance this ubiquitous, intensifying war against nature. We know that a global meat complex that "processes" billions of animals yearly is widely regarded as a sign of affluence, development, good health, modernity. It is, incidentally, among the biggest contributors to global warming and assorted environmental dangers such as deforestation, ocean pollution, and biodiversity loss. ${ }^{54}$

Conventional political discourse that romanticizes the "unification of humans and nature," whether Marxist, liberal, or some other, is meant to sound enlightening but points toward exactly the opposite - a cruel fraud. Could such a fraud be morally tolerable within a viable socialist politics? Sanbonmatsu's answer: “. . . to affirm socialism without animal liberation is to affirm 
a civilization based on a continual antagonism with the rest of nature." ${ }^{55}$ Idealization of Nature (caps intentional) turns despotic under the most progressive of ideological covers. As for Marxism, even "ecological Marxism" in the name of "science" and "materialism," what ought to affirm deep moral, ecological, and political concerns end up obscured in the fog of productivism. It is no secret that neither Marx nor Engels (said to be a fox hunter) ever questioned the prejudice of anthropocentrism or speciesism in their own time, in effect laying the theoretical underpinnings of political debility for later generations of Marxists and socialists. As more refined technological methods of mass killing are employed by huge corporate meat and dairy interests, as nonhumans wind up more (not less) central to the power of agribusiness and source of capital accumulation, political opposition winds up silent and ultimately complicit. Meanwhile, the globalized power structure proceeds along with its routine, but deadly, course.

What kind of ecosocialism might flourish within such a yawning theoretical and political void? What kind of radical politics could effectively support this aggravated warfare against the natural habitat? What could justify a structure of power so willfully responsible for the worsening ecological crisis - contributing not only to climate change but to exhaustion of natural resources, destruction of biodiversity, and shrinking arable land, not to mention the depletion of oceans and forests? As the planet further descends into catastrophe, those few critical thinkers with the audacity to raise such deeply-ecological concerns are sadly derided by leftists as "extremists," "food fascists," and worse, often reminded that, after all, "Hitler was a vegetarian" (he was not, though it is irrelevant). Even the existing marginal opposition to speciesism is trivialized, the worst forms of animal exploitation comfortably ignored while more enlightened critics tend to the "bigger issues" and work to "save the planet."

One aspect of speciesism - what humans eat on a daily basis - is perhaps the most troublesome of all problems, yet the most concealed and least understood. Richard Oppenlander, in his unsettling book Comfortably Unaware, argues that meat consumption is doing more to destroy the Earth than anything else. "Global depletion in some form will occur," he writes, "simply because the earth can only support so many people doing so many things over so long a period of time." He adds: "We have developed a complex system of producing more and more animals that use more and more of our resources, while leaving a massive amount of waste, and climate change in their wake. . This system has become complicated in that it is now heavily intertwined with our culture, politics, economics, and the suppression of the reality of its effect on our planet." Ecological rationality demands a public accounting of this dreadful reality, yet willful ignorance prevails instead. Oppenlander laments: "To make matters worse, individuals and institutions that are in a position to expose myths, enlighten the public, and change the direction of public opinion clearly are not doing so." ${ }^{56}$ The reference here is to American public opinion, but it is just as applicable to most other countries.

Issues related to agriculture and food consumption deserve far more attention than they have gotten, especially when it comes to progressives and Marxists. As for Marx, his views on the topic did not extend very far. The authors of Food, Politics, and Society point out that he "overlooked the role of what we have called the 'food system' is itself a driver of social, economic, and political transformations." 57 This system, perhaps more than any other, lies at the core of historic changes in the relationship between agriculture and industry, agrarian and urban life, development and ecology - clearly vital to any in-depth understanding of the modern crisis, any move toward ecosocialism. Within this matrix, problems of everyday consumption, environmental deterioration, corporate power, and vast health challenges of our time are thoroughly interwoven.

Lester Brown, writing in Full Planet, Empty Plates, argues that food politics nowadays engages - or should engage - what is most central to facing the challenge of ecological unsustainability. Thus: "We are entering a time of chronic food insecurity, one that is leading to intense competition for control of land and water resources - in short, a new geopolitics of food." ${ }^{58}$ Rising global meat consumption surely poses one of the biggest challenges - again, scarcely acknowledged, even among ecologists. More than at any time in history, the animal-based food system veers out 
of sync with land availability, natural resources, climate stabilization, human health, and survival of thousands of other species. One can only ask: could such immeasurable human assault on "nature" be adequately captured through the notion of "metabolic rift"?

Returning to Marx, the very notion of harmony in natural relations had, in fact, already been torn asunder, fractured under the onslaught of industrialization, urbanization, and warfare. The dialectical synthesis of humanism-naturalism was never historically grounded, whether before or during the rise of capitalism. The concept of nature in Marx, Ted Benton argues, was always flawed by a sharp dualism visible, for example, in those frequent passages dividing humans from animals. ${ }^{59}$ Humans arrogantly retain the capacity to treat (especially this part of) nature by means of crudely instrumental practices - a legacy ritually forwarded by later generations of Marxists and socialists. Those who celebrate an "ecological Marx" usually fall silent on the painful question of human-animal relations as if "nature" did not extend to many billions of nonhuman beings, other species with their own subject of life, their own capacity to suffer pain and loss, their close interaction with (and often dependency on) human populations. One can only conclude that such ethical neglect mirrors an incomplete, callous, utilitarian conception of nature.

In their book Creating an Ecological Society, Magdoff and Williams are perfectly content to proclaim the truism that all living organisms are connected to each other - integral to cohesive ecosystems -- then proceed to call forth Marx's refrain that humans are uniquely thinking, planning beings whereas other species remain trapped in their physical immediacy - only partially true, but in any case irrelevant to a world of unspeakable atrocities committed by humans against animals. While conceding meekly that modern agribusiness is "cruel to animals," Magdoff and Williams quickly curtail their passion for nature and concern for corporate savagery: the global meat complex is fine so long as it is organized around "integrated farming systems" that (with meat products) supply high-quality protein foods - ignoring the fact that plant foods supply better, healthier, and more ecologically-friendly sources of nutrition (not just protein). By conveniently ignoring the horrendous impact of animal-based economies, the authors can go no further than vague references to "humane practices." 60

Armed with this tormented logic, contemporary Marxists predictably drift toward the camp of corporate giants like Tyson Foods, Monsanto, Cargill, and McDonald's - all deriving their criminal profits from an all-out war against nature. Formally progressive ideas coexist with tightening systems of domination so pervasive, so normalized, as to be nearly invisible. The cruelest violations of nonhuman life are taken for granted, allowing humans to psychologically and socially detach themselves from daily mechanisms of destruction. ${ }^{61}$ All the accumulated references to "species-being," human-nature unity, and liberation from necessity can never conceal this systematic and deliberate transgression of the natural world - a topic entirely ignored by Saito.

\section{Science - or Scientism?}

Was the revolutionary theory developed by Marx across three or more decades actually a form of scientific analysis, as many later interpreters have claimed, or something entirely different more akin to a critical theory, a "philosophy of praxis" affirming the unity of theory and politics? The question as to whether Marx's work, on the whole, was scientific no doubt matters, as its status determines how we view its numerous historical claims, its political efficacy, and surely also its ecological relevance. (While Marx and Engels worked in tandem on some major writings, epistemological differences appeared to surface toward the end of their careers.) Debates over to what extent classical Marxism could lay claim to scientific validity - or could be viewed in such terms - would pervade the tradition up to the present. Champions of an "ecological Marx," including Saito and Foster, have generally arrived at a scientific reading of both Marx and Engels, endowing their work with a firm grounding in some variant of "dialectical materialism." Both 
Saito and Foster do make a point to distance their approach from cruder forms of positivism.

While Marx's outlook has been widely understood as "materialistic" (thus also presumably scientific), the same theoretical edifice that would by the 1930s morph into official Soviet Marxism, it is worth noting that Marx himself scarcely employed the term in any philosophically consistent way. Engels was more inclined to embrace materialism in his theoretical writings, most often in texts like Dialectics of Nature, completed after Marx's death. Marx's philosophy, going back to his early years, actually differed from that of Engels - and the later scientific pretensions of Kautsky, Plekhanov, and many leading figures in European social democracy. Engels had argued in Dialectics that matter fundamentally precedes ideas and consciousness; the subjective realm was little more than a reflection of the external world, worthy at best of secondary importance. Marx himself never fully shared this outlook. In fact, the stricter version of materialism later adopted by Engels and his disciples was identical to the very mechanistic theories Marx had earlier criticized in Theses on Feuerbach.

Marx's own philosophy was never strictly materialist or scientific in ways his writings have so often been interpreted. He remained much too indebted to his strong Hegelian origins to adopt such an outlook, yet critical enough of Hegel and other German idealists to avoid following in their footsteps. For Marx, historical development was much too complex to be regarded as a simple unfolding of objective forces independent of human thought and action; social change always depended on some type of subjective intervention. It might be argued that Marx's epistemology was formed sui generis, a dialectical synthesis of earlier materialism and traditional idealism - a prelude to what Gramsci would later refer to as a "philosophy of praxis," the approach both believed was most consistent with the demands of revolutionary politics. As such, it avoided the rigid dichotomy subject/object of historical transformation.

For Marx, conscious human activity (including politics) was fundamental to revolutionary change. From this standpoint, it seems probable that Marx's heightened attention to the natural sciences after 1868 did not necessarily coincide with efforts to adopt a scientific methodology for purposes of explaining human behavior or, by extension, the dynamics of social change. Moreover, it cannot be assumed that Marx shared all facets of the later Engels' more rigorous materialism, though, as mentioned, he was at least partially involved in some thought-processes that informed Anti-Duhring. There is no evidence to suggest Marx viewed historical development in rigidly scientific terms consistent with Engels' later work - or with Nicholai Bukharin's materialist sociology of the 1920s. In this realm as in others, what later became known as "scientific" theory, within and outside Marxism, turned out to be no more than normal pursuit of knowledge through well-grounded historical analysis, with positivism often something of a veneer. The much-celebrated "science of society" in effect amounted to meticulous efforts to identify and analyze broad tendencies of historical development.

One problem with materialist philosophy is that its overwhelming focus on the objective (material) side of history must inevitably devalue the subjective side, which Marx himself viewed as indispensable to revolutionary change. Without decisive political intervention - a realm of creative vision and action - it would be hard to imagine a process of far-reaching transformation. Longstanding debates over whether and to what degree a strict materialist approach can be attributed to Engels alone has served to muddy the scientific imprimatur of classical Marxism. European social democracy, for its part, was for years divided between Kautsky's uncompromising materialism and Bernstein's "pragmatic" reformism, while Rosa Luxemburg has usually been identified with the "spontaneist" masses-make-history approach. Lenin, influenced by Plekhanov, initially embraced a scientific approach laid out in Materialism and Empirio-Criticism, then turned toward a praxis-oriented philosophy in the 1914-16 Philosophical Notebooks where he is said to have "rediscovered" Hegel. The main architect of the Bolshevik Party and October Revolution, Lenin would naturally be inclined to valorize subjective intervention (later referred to as the "external element") as essential to transformative politics. Toward the end of his life, Lenin (and other Bolsheviks) came to regard "dialectical materialism" as a recipe for intellectual contemplation and political passivity - a rather conservative outlook. It would be Stalin, of 
course, who managed to bring "Diamat" into the realm of official Soviet ideology. ${ }^{62}$

The limits of scientific materialism become all the more evident once classical Marxism is situated in its historical period - the early decades of capitalist development. While the theory might have been identified with elements of universality, even the brilliant Marx and Engels could never fully escape the limits of their era; they too were in some way products of the Zeitgeist. It is thus hardly coincidental that Saito's treatment of Marx revolves around categories of classical political economy - capital formation, commodity production, reification, exchange relations, and so forth. This makes sense as part of a faithful effort to capture the main dynamics of Marx's thought, meaning Saito's treatment is appropriately historicized. Of course, the world has changed beyond recognition since the mid-nineteenth century, a market-centered capitalism superseded long ago by a globalized system of corporate-state domination that would be unrecognizable to Marx and Engels. We have available no widely agreed-upon-identifiable scientific methods - no rigorous "laws" - that could thoroughly analyze this epochal change, much less the epochal political events of the twentieth century.

The contemporary world system, associated with advanced capitalist rationalization along with imperialism, wars, and revolutions, bursts the old categories of early capitalism that serve to delimit the scope of Saito's work. These newer factors scarcely enter Saito's panorama of concerns, understandable given his focus. Scientific materialism obscures more than it illuminates when facing the contours of historical disorder and lawlessness. Insofar as this is true, prospects for renewed ecological theorizing based on traditional categories would appear futile. The problem, once again, can hardly be laid at the doorstep of Marx and Engels, or even Kautsky and Plekhanov. Rather, the difficulty lies in strained efforts by "ecological Marx" proponents to scientifically legitimate their claims of a new theoretical breakthrough. Viewed historically, therefore, theory (Marxist or otherwise) cannot but reflect the contours of its own time. In his dialectical synthesis of materialism and idealism, Marx himself formulated a philosophy of praxis sufficiently historicized to avoid certain pitfalls. Not so, unfortunately, for so many "heirs" of Marx. By the late twentieth century, the system of corporate globalization had already grown so concentrated, so expansive, so riddled with newer conflicts that more resonant categories of analysis would be obligatory.

Whatever its scientific claims, one can see how theory evolving within an organizational setting can become easily ritualized, neutralized by oligarchical pressures, rendered more or less lifeless. Of course, Marxism has not been spared such pressures, a tendency explored by Frankfurt School theorists, especially by Herbert Marcuse in his classic Soviet Marxism. Marcuse writes that for Soviet Marxism the theory ". . . has undergone a significant change: it has been transformed from a mode of critical thought into a universal 'world outlook' and universal method with rigidly fixed rules and regulations, and this transformation destroys the dialectic more thoroughly than any revision. The change corresponds to that of Marxism itself from theory to ideology; dialectic is vested with the magical qualities of official thought and communication." Here Marxism "ceases to be the organon of revolutionary consciousness and practice and enters the superstructure of an established system of domination." 63

In the West, the fate of twentieth-century Marxism has more or less mirrored the very trajectory of capitalist rationalization, shaped and re-reshaped by the process of modernization and what is essential to it: science, technology, and bureaucracy. Any supposed "laws of development" here have little in common with capitalist tendencies emphasized within classical Marxist texts. This is not to suggest that Marx's theorization of the capitalist political economy for his time - whatever its flaws - is to be judged as anything but superlative. By the late twentieth century, however, the steady expansion of corporate-state power, transnational institutions, and technological rationality called for newer categories of historical analysis.

Among the newer concerns (leaving aside the ecological crisis) is the growth (and use) of military force, which dominates the global landscape at a time when resource wars are sure to intensify -- a crisis and response pattern that in itself explodes the conceptual parameters of nineteenthcentury Marxism. Capitalist globalization has unleashed the destructive power of militarism and 
war, from World WII to the present, carried out, technologized, and legitimated through the vast achievements of modern capitalism, culminating in sophisticated modes of technowar. Postwar U.S. militarism alone has brought unspeakable carnage to the world, driven and legitimated by science and technology. Referring to the Vietnam debacle, James William Gibson writes: "War managers are at the top of the stratification system. They think in instrumental categories taken from technology and production systems, and the business accounting rationales of the debit and credit ... and had a virtual monopoly on socially-accepted 'scientific' knowledge." ${ }^{64}$ As with the architects of Hiroshima and Nagasaki - and urban terror bombings in many countries -- that "knowledge" was fully detached from its horrific consequences.

Several decades ago, Horkheimer's seminal distinction between "traditional" and "critical" theory situated classical Marxism within the latter, its passion for regularity, rigor, and lawlike tendencies resonant with the "given order of things." Such mechanistic thinking, in his view, could never grasp the chaotic, irregular, indeterminate elements of historical change - precisely what happened to characterize so much of twentieth-century politics. The dynamics of social psychology, the point at which individuals engage society and history, was met by "traditional" theorists with some indifference, probably deemed beyond theoretical coherence owing to its often irrational, unpredictable character. The more scientific (or scientistic) the framework, the more burdensome will be efforts to analyze historical events - one of several reasons the transfer of investigative methods from physical to social sciences was destined to fail. ${ }^{65}$ The fact that Marx himself never fell for such pretenses did not, unfortunately, deter later disciples.

For scientific materialists, the space for collective subjectivity (politics foremost) was something of an after-thought, peripheral at best. The search for ironclad regularities in social behavior has obvious anti-political consequences; one reason Lenin chose to abandon his earlier materialist philosophy when what Georg Lukacs called the "actuality of revolution" gained momentum in Russia. On this point, Sheldon Wolin has more recently called attention to the innately "fugitive" character of politics - a realm given to the unsettled and unpredictable, resistant to established patterns. ${ }^{66}$ Experience suggests that political action has rarely been theorized with precision, for that would clash with the typically multifaceted, unstable features of historical change. No one has yet discovered a "political science" reliable enough to determine what truths might be valid across widely-diverse ideological viewpoints, and Marxism has been no exception. The standpoint of objectivity or neutrality cannot be sustained in a context where knowledge must be obtained through selective criteria of focus and interpretation. In Wolin's words: "Perforce, a political theory is among many other things a sum of judgments shaped by the theorist's notion of what matters, and embodying a series of discriminations about where one province begins and another leaves off." ${ }^{67}$ There is no convincing reason why Marxism should be exempt from such maxims.

Kindred arguments were put forward decades ago within Marxism itself, most systematically by Gramsci. In re-framing Marx's original philosophy of praxis, Gramsci turned his attention to the nexus history-philosophy-politics that he contrasted with the more fashionable materialism of his day, identified first with the Italian Marxist Amadeo Bordiga and later with Soviet theorist Bukharin, greatly praised by Foster. In the Prison Notebooks, Gramsci attacked such materialism is both philosophically and politically constricted, a source of intellectual detachment. His work turned to an emphasis on historicism, since: "The philosophy of a historical epoch is nothing other than the 'history' of that epoch itself . ..", here revealing the influence of Benedetto Croce and Italy's first Marxist, Labriola. ${ }^{68}$ To properly engage Marxism, it too would have to be historicized to avoid schematic or ritualized formulations. In Gramsci's case, the philosophy of praxis captured a revolutionary impulse generally regarded as fundamental to Marxist politics. Transhistorical generalizations, abstract regularities, and rigorous "laws," he argued, have maximum validity only under conditions of mass disempowerment, political inactivity. Thus: "It should be observed that political action tends precisely to rouse the masses from passivity, in other words, to destroy the laws of large numbers." ${ }^{9}$ Elsewhere Gramsci frames Marxism as a theoretical structure with special temporal relevance in the form 
of "absolute historicism."70 Put differently: "Separated from the theory of history and political philosophy cannot be other than metaphysics . . .."71 (Here Gramsci in effect proceeded to turn the scientific materialism of Engels, Plekhanov, and Bukharin on its head, dismissing it as a newer form of "metaphysics".)

Proponents of an "ecological Marx" grounded in scientific methods are usually dismissive of "Western Marxists" like Gramsci and Lukacs owing to their supposed distance from the real world of political activity - a criticism also directed at theorists of the Frankfurt School. In the case of Gramsci, however, the charge is entirely misplaced: in his early years, Gramsci was a leading activist in the Italian Socialist party, then became an influential theorist of the factory-council movement, before co-founding the Italian Communist Party (PCI), serving as a parliamentary deputy, and spending the last decade of his life in fascist prisons. This biographical reference is meaningful insofar as it contradicts the longstanding fiction that a critique of strict materialism implies a form of religious or spiritual resignation.

\section{| Marxism in History}

Traversing the modern historical terrain, it seems worth revisiting the question as to whether Marxist theory can be a source of oppositional politics for the twenty-first century. Such questions, we know, were posed long ago for the twentieth century. Does the case for an "ecological Marx," however scientific, have resonance for an era of deepening global crisis? Earlier Marxism in its multiple variants did, of course, help fuel the rise of movements, unions, parties, and governments in Europe and beyond, though increasingly with limited anti-system possibilities. The rich intellectual heritage continues to this day, within artistic circles, universities, and media culture, especially in the West. In deradicalized form, it continues to provide ideological legitimacy for such regimes as China, Vietnam, and North Korea.

A Marxism of sorts first emerged in the period spanning the 1840 s to 1870 s, then reached its heyday between the 1880s and 1920s, crucial to the rise of both Second (Socialist) and Third (Communist) Internationals. In some ways, a mirror reflection of early capitalism, Marxism was widely understood in terms of its imputed universality, even scientificity. Yet the main analytical focus of traditional Marxism - competitive markets, commodity production, proletarian expansion, intensifying class conflict - would eventually lose political relevance in an age of merging corporate and state interests, oligarchic rule, militarization, technological rationality, and novel forms of ideological hegemony. The modern behemoth would be reinforced by rapidly-sweeping globalization - not only in the economy, but in politics, culture, technology, and communications. Meanwhile, the post-World War II era witnessed unimpeded growth of the U.S. as a leading superpower, an imperial Leviathan with hundreds of military bases scattered across the globe, launching pad for perpetual wars, and armed with enough nuclear weapons to destroy the planet many times over.

Since just after World War I, anti-system politics has experienced a steady decline - whether speaking of labor movements, local councils, social movements, political parties, or international organizations. Revolutionary optimism that might have infused the first decades of the twentieth century continued to wane, thanks in part to the rise of both fascism and social democracy. By the end of the century, it could be said that Marxism no longer presented a threat to capitalism anywhere on the planet. Despite its ongoing dysfunctions, contradictions, and crises, modern state-capitalism is today probably stronger than ever, seemingly immune to direct overthrow. Hardly anyone in the twenty-first century believes the famous economic crisis-tendencies of capitalism will pave the way toward socialism - though crisis-tendencies, of a different sort, do indeed persist.

Given such reality, obvious questions arise - among them, whether this deterioration of Marxist politics might stem from the kind of scientific claims we have come to associate with the portrait of an "ecological Marx." What might be the efficacy of a materialist philosophy like that 
embraced by Saito and Foster at a time when distinctly political hopes are so remote? Facing the specter of obsolescence, where does an intellectual paradigm rooted in the very distant past achieve unmovable certitude in the face of an unprecedented, complex, rapidly-moving global crisis? My conclusion, evident from arguments presented so far, is that Marxism has become so theoretically marginal that hopes for an "ecological Marx" are now best regarded as illusory.

The Marxist tradition - notably that tendency adhering most closely to the classics, to scientific materialism - has been a poor guide to the most consequential developments and events of twentieth-century politics, and beyond. As noted, it has long been commonplace that the Bolshevik Revolution violated nearly every precept of Marxist theory that preceded it, despite later adoption of the "Marxist-Leninist" label by the Soviet and other Communist regimes. The Russian success was not widely anticipated before the war, much less predicted, by Marxists at the time, many fearful of Bonapartism. Following the Bolshevik conquest of power, Gramsci wrote his seminal "Revolution Against Capital," referring to a historical moment made possible by imperialism and war rather than the "lifeless facts" of political economy. The work of Marx and Engels, it turned out, had, in reality, little to offer Lenin and the Bolsheviks. For Gramsci, a real living revolution in Russia collided with old theoretical schemas, however elaborate and rigorous. Those schemas allowed no room for the socialist insurrection in countries that had not yet experienced capitalist industrialization, and Russia was still largely a peasant society, with no liberal-democratic past until World War I. But events ultimately proved more decisive, more powerful than even the most sophisticated conceptual paradigms. ${ }^{72}$

Drawn to Lenin despite earlier involvement in the Turin factory-council movement, Gramsci already by 1918 saw advantages in a vanguard party that could orchestrate epic historical change. No doubt Lenin's Jacobinism brought to Gramsci' mind the rich Italian legacy of Machiavelli and The Prince. ${ }^{73}$ The party functioned not only as a mechanism for seizing state power but as a vehicle of mass mobilization - neither concern seriously addressed within classical Marxism. In Russia, of course, capitalism was both poorly-developed and mostly foreign, meaning that revolutionary change would have to proceed against the main contours of Capital and the world it reflected, against what Gramsci called a "book of the bourgeoisie". He wrote: "Why should they [Russians] wait for the history of England to be repeated in Russia?, adding: "History is not a math calculation; it does not possess a decimal system, a progressive enumeration of equal quantities ..." ${ }^{74}$ In the end, despite all the inflated claims of Engels, Kautsky, Plekhanov, and (in Italy) Bordiga, actual historical forces ended up sweeping aside "every pre-established schema". 75

By virtue of his searing critique of the nexus economism/spontaneism, Lenin was able to "solve" the problem of revolutionary consciousness left open by the Marxist classics. The focus, as noted, was on what Lukacs would later refer to as the "actuality of the revolution" - that is, a sharp turn toward the subjective element of historical change. Strict theoretical formulas were disdained as a path toward ideological passivity and political inertia. ${ }^{76}$ Since there were precious few insights from Marx and Engels as to how class solidarity was expected to develop, Lenin's stark response was that mass consciousness, under conditions of bourgeois rule, could never escape its own social immediacy. That would be the task of revolutionary intellectuals who, able to operate more freely against a suffocating power structure, would furnish the badly-needed "external element" as a political vanguard. Wrote Lukacs after the revolution: "The Leninist party concept represents the most radical break with the mechanistic and fatalistic vulgarization of Marxism." 77 (The great Hungarian theorist of class consciousness would himself come around to Leninism in the years following the Bolshevik Revolution.)

It turned out that classical Marxism would have little to say about the most dramatic events of the twentieth century: several Communist revolutions, the rise of fascism, the scourge of imperialism and militarism, two world wars, the phenomenon of corporate globalization. As for the Bolshevik Revolution, it opened up a new phase of revolutionary change at a juncture of imperialism, wars, Jacobin politics, the ascendancy of state power - well beyond the scope of Marx and Engels. The October events were a product of richly-complex variables, not least being the decisive role of a vanguard party. Contrary to any widely-accepted "laws" of historical 
transformation, Lenin and the Bolsheviks set about reordering society on their own terms, relying heavily on instruments of political organization and state power.

Contrary to facile generalizations about capitalism (e.g., the "falling rate of profit"), the variables here were multiple, rapidly-changing, global, largely unpredictable. Commenting on the Russian events, E. H. Carr wrote: "It would have been an astonishing anomaly if that revolution, far removed in time and space from anything Marx knew, had conformed in detail to the prescriptions of classical Marxism." 78 Indeed Bolshevik exploits conformed more closely to Lenin's What is to be Done? than to anything Marx wrote in Capital or any other text. Lenin himself eventually had no problem with such an assessment. Writing in Left-Wing Communism, after the revolution, he reflected: "History as a whole, and the history of revolutions, in particular, is always richer in content, more varied, more multiform, more lively and ingenious than is imagined by even the best parties, the most class-conscious vanguards of the most advanced classes." 79

One can go further: revolutionary movements, by definition, involve chaos, disruption, and uncertainty under circumstances where the lives of millions of people are overturned, their habits, rituals, and patterns of social existence altered, probably forever. That was emphatically the case in Russia, roughly duplicated in later twentieth-century Communist upheavals. Writing in The Proletarian Revolution and the Renegade Kautsky, Lenin asked: "Are there historical laws governing revolution which know of no exceptions? No, no such law exists. These laws only apply to what is typical, to what Marx once termed the ideal, in the sense of an average, normal, typical capitalism". 80 (There has never been anything resembling "typical capitalism.") Most of all, Lenin was a great believer in creative, even Promethean intervention - a dreamer, romantic, utopian, adventurer - in the service of the revolution.

In reality, Leninism marked not so much a "vulgarization" of Marx but a process of overturning, or negating, as Gramsci had essentially argued. What earlier theorists had not seen, according to Lukacs, was the dramatic historical (and political) impact that imperialism and war would have not only on Russia but across the world. This necessary insight would have its validity repeated across later decades, transforming geopolitics forever. The Marxist classics offered little wisdom here, devoid as they were of any useful theory of revolutionary change. Leninism, on the other hand, would be decisive for insurrectionary politics across the twentieth century, the vehicle of a party-state commanding enough to destroy the old centers of power. They were all to some degree "revolutions against Capital": Russia, China, Yugoslavia, Vietnam, Cuba. All succeeded in the historical context of imperialism, war, and popular struggles against foreign occupation. ${ }^{81}$ Mass energies were galvanized by an intense nationalism that politicized not only workers but peasants, the middle strata, and other groups. Once state power was taken, Leninist elites pursued two interwoven objectives: national independence and economic modernization, first visible in the Soviet path charted in the 1920s. Those objectives made sense in countries that were not yet industrialized, a reversal of classical Marxism as the primacy of economics gave way to the primacy of politics.

If Marxism was never much of a guide to actual revolutions, it would become even less relevant to those (post-capitalist) societies as they evolved over time. The eventual trajectory was either bureaucratic centralism (the USSR, North Korea) or some variant of state-capitalism (Yugoslavia, China, Vietnam). While elites adopted "Marxism-Leninism" as legitimating doctrine for maturing Communist regimes, that ideology bore little resemblance to actual development much less basic categories of Marxist theory. The process of ideological ritualization went so far in the Soviet Union - became so detached from everyday reality -- as to eventually contribute to regime collapse. Since the Cuban events of 1959-60, when agrarian revolt rapidly turned Communist, there has been no revolution like those mentioned above, an expanse of fully six decades. More telling, there have been no victorious proletarian revolutions in any advanced capitalist society.

As for working-class upsurges in any setting, only four have achieved what might be considered revolutionary potential: Italy in 1919-20, Spain in 1936-39, Italy during World War II, 
Poland in the early 1980s (directed against Communist rule). In fact, only the first Italian case - the great postwar Biennio Rosso uprisings - would broadly fit the conventional Marxist idea of proletarian revolt against capitalist power, which failed exactly one century ago owing to its geographical (and political) isolation. That failure would immediately be followed by the world's first fascist conquest of power, which revealed the very uneven level of class consciousness among northern Italian workers. ${ }^{82}$ Across Europe since World War II, labor has generally supported unions, parties, and (both local and national) governments that have uniformly experienced deradicalization.

If years of warfare gave rise to a mass insurgency in Italy during 1919-20, similar conditions materialized toward the end of World War II, giving rise to the anti-Nazi Resistance movement. As in the case of Leninist revolutions, this was a multiclass "historical bloc" mobilized around strong nationalist appeals, usually led mostly by Socialists and Communists. Between 1942 and 1945, the Italian Communists grew from a pre-war nucleus of perhaps five thousand militants to a major political force with over two million members and control of several large cities and some provinces. Partisan forces across the country were incited by many of the same conditions as in Russia, China, and other aforementioned cases. None could be explained within a Marxist framework.

For the history of proletarian upheavals as such, the record since the Biennio Rosso has been dismal, while even that episode is frequently described as "the revolution that failed." The overall trajectory of decline can be situated partly within the relentless process of capitalist rationalization, less a function of leadership betrayal or working-class "immaturity." The epic growth (and convergence) of corporate and state power, the bureaucratization of society, and new forms of ideological hegemony have bolstered elite power, institutionalized class conflict, and reinforced political legitimation throughout Europe and beyond. Further, with heightened rationalization and globalization has come to the political decline of the working class in both numbers and leverage.

While Marxism in scholastic form retains appeal to intellectual groups in the West and elsewhere, in both theory and practice, it no longer represents even a slight threat to capitalist stability. The capitalism described by Marx - and faithfully reconstructed by Saito - was a system of commodity production, market relations, expanding proletariat, limited state power, and relatively feeble ideological controls. Weber's emphasis on state-corporate domination, technological rationality, and bureaucratization of public life far better captured the twentiethcentury capitalist developmental pattern. Attention to ruling-elite capacity to erect a solid apparatus of domination was foundational to the work not only of Weber but (in different ways) also of Gramsci, the Austro-Marxists, and so-called "elite theorists" -- Robert Michels, Vilfredo Pareto, Gaetano Mosco - all to varying degrees influenced by Weber. That influence would extend to the later work of C. Wright Mills in The Power Elite, which combined Weberian and Marxist approaches. None of these theorists, however, dealt systematically with the problem of globalization and the ways in which it served to expanded capitalist power and weakened political opposition. To the extent this was the case, one cannot but wonder how the phenomenon of globalization could profoundly alter a body of theory shaped by nineteenth-century capitalism. Whatever the current prospects for ecosocialism, the path forward is destined to move along rather different tracks than those laid down by Marx and Engels.

As noted, the sources and dynamics of revolutionary consciousness were never adequately explored by Marx or Engels. It could be that for the Marxist classics, this problem would somehow get worked out through the very dialectics of historical transformation - a premise that, as we have seen, could not be sustained. What then? Lenin (Jacobinism) and Bernstein (reformism) would arrive at their own competing solutions at the start of the twentieth century, others joining the strategic debate later. None, however, would find much theoretical solace in earlier Marxist writings. Where such crucial questions were left unattended, there could be no meaningful revolutionary theory. That would turn out to be yet another implication of Gramsci's "Revolution against Capital": the texts contained nothing very helpful about the social 
psychology of consciousness formation, much less the organizational and strategic requirements for winning state power.

It might seem puzzling that neither Marx nor Engels, dedicated socialists, ever arrived at a theory of revolutionary politics, but that is indeed the case. One difficulty was the very fragmented character of their work on topics related to politics and the state, which in any case they had devalued as "superstructure" relative to the economic "base." That could at least partly account for their meager interest in processes whereby those most exploited might arrive at the psychological rejection of the status quo - meaning a traumatic break with long-established patterns of social and individual life. We have seen that Lenin believed workers could never develop class consciousness when left to their own resources, needing a particularly robust "external element." Confined to trade-union activity, the proletariat would never get beyond a path of limited reforms. Revolutionary politics, on the other hand, would depend on the organizational and ideological coherence of a fighting party. In this, Lenin discovered a vital historical truth: class consciousness would never arise from organic, local, spontaneous activity, nor would it result from the development of "objective" historical forces. Lenin's epic departure from classical Marxism would be taken up (and further elaborated) by Gramsci and other Marxists of the Third International -- a linchpin, as noted, of twentieth-century Communist revolutions.

For both Lenin and Gramsci, the episodic and unpredictable ("fugitive") moments of historical change, marked a cycle of responses and counter-responses, was more decisive than any "science" or "laws" of development. Class consciousness was formed within a complex ensemble of psychological attitudes, feelings, and beliefs, most keenly aroused at times of social turmoil and political breakdown, Gramsci writing that "history sweeps aside every pre-established schema." 83

If Marx had been able to critically analyze the broad patterns of nineteenth-century capitalism, his theory paid little attention to the subjective elements of change, despite suggestive insights here and there. On the one hand, Marx looked to the steady expansion of an oppressed, alienated proletariat whose very life-conditions would generate anti-capitalist consciousness, a step toward the transition to socialism. Widening contradictions of an economic system that could never satisfy general material needs, one that perpetuates opposition, would sooner or later give rise to (both objective and subjective) revolutionary conditions. Consciousness itself never seemed much of a priority insofar as it was thought to be a natural outgrowth of intensifying class conflict. Marx's political outlook, in fact, suffered from the hindrance of a simple rationalist psychology, where material self-interest would be seamlessly translated into anti-capitalist attitudes and beliefs. We know from abundant historical evidence; however, that mass politics rarely follows such rationalist premises.

Marx thus never arrived at an understanding of how people might become active (collective) subjects or agents of history - how alienation might be overcome. References to a future socialist society do not suffice. This very question was faced head-on by Lenin and Gramsci, as they embarked on a journey of revolutionary politics. That defect of classical Marxism as it evolved following Marx's death was partly a function of scientific materialism that, for Europe at least, would become the burdensome legacy of Engels and Kautsky, the same legacy resurrected decades later by proponents of an "ecological Marx." The political outlook shared by Lenin and Gramsci revolved around the issue of ideological domination that Gramsci would famously define in the Prison Notebooks as "hegemony": the role of religion, education, and culture in sustaining ruling-class legitimacy. ${ }^{84}$ That legitimacy, as historical experience reveals, allows even shaky power structures to survive great economic crises and even wars. Over the past century, of course, mechanisms of ideological control available to capitalist elites (above all in media and communications) have expanded beyond anything imagined by Lenin or Gramsci. For that same period, Weber foresaw that capitalist rationalization would contain insurgent consciousness and subvert radical politics. Gramsci also understood this process fully, laid out in his oft-overlooked essay "Americanism and Fordism" in the Notebooks. ${ }^{85}$ Concentrated power would enlarge organizational and ideological controls across public life, most emphatically in the expanding 
Fordist (Taylorized) workplace. As workers and others submit to hegemonic norms, beliefs, and laws, their social individuality yields to relentless conformist pressures.

The problem of revolutionary politics within Marxist theory deserves far more attention than it has generally received. Here it is worth considering how twentieth-century thinkers (Marxists and others) managed to fill a void in the Marxist classics regarding consciousness-formation and, by extension, political conditions of an expected shift from capitalism to socialism. From Lenin to Gramsci, from Lukacs to Marcuse, the verdict regarding a potential class-conscious proletariat in the West has been typically bleak: capitalist development, in whatever setting, meant subordination of workers to bourgeois domination - a conclusion at odds with Marx's wellknown optimism. Many decades after Marx and Engels passed from the scene, that problem for Marxists would remain and even deepen.

Lenin's argument, mostly taken for granted by later generations of Communists, stressed that the power elite would always have the upper hand "for the simple reason that bourgeois ideology is far older in origin than socialist ideology, that it is more fully developed, and that it has at its disposal immeasurably more means of dissemination." 86 While Marxism has emphasized the organic (or spontaneous) element of workplace struggles, Lenin (against prevailing SocialDemocratic opinion) assigned Promethean importance to a radical intelligentsia, drawing on its unique tradition in Russia.

Given a lack of faith in proletarian self-activity, Lenin turned to an organization of professional cadres - the new repository of socialist consciousness. Leninism would later have its well-known authoritarian consequences - and of course, its critics, starting with prominent Mensheviks such as Peter Struve and the eminent Plekhanov, later including the radicals Rosa Luxemburg and Anton Pannekoek, both dedicated to mass spontaneity. Among Lenin's harsher critics was Jan Waclaw Machajski, convinced the Bolsheviks constituted the makings of a "new class" of intellectuals aiming to manipulate popular energies behind industrialization under a contrived (socialist) banner. As for the workers, still bereft of self-activity, they would go on being exploited and controlled by just another ruling elite. ${ }^{87}$

What favored a revolutionary outcome was a large-scale organization, built on command principles, dynamic leadership, coherent ideology, a strategy for winning state power. Machajski's thesis, on the other hand, happened to finally converge with Weber's thesis of capitalist rationalization, which fixated on the expanding role of government, bureaucracy, and technology integral to modern European economies. Ironically, at the very moment, Lenin and the Bolsheviks were drawn to organizational politics, American capitalism (driven by auto assemblyline production) was introducing tighter controls in the form of Taylorized scientific management.

The Weberian theory would have considerable influence across succeeding decades - first among the "elite theorists" and Austro-Marxists, then among Frankfurt School intellectuals (notably Marcuse) and the later work of Mills. Even Gramsci, as noted, bore the imprint of Weber. Michels, in contrast to Lenin, called attention to the innately conservative features of large-scale organization, visible during his own time for its anti-democratic impact on unions, parties, and governments. The German Social-Democratic Party (SPD) that Michels studied was just as vulnerable as any other - its leadership able to take advantage of the psychological "incompetence of the masses," a motif that in the end differed little from Lenin's "ideological enslavement" argument. Wrote Michels in 1911: "Political organization leads to power. But power is always conservative." 88 And: "Thus the majority of human beings, in a condition of eternal tutelage, are predestined by tragic necessity to submit to domination by a small minority, and must be content to constitute the pedestal of an oligarchy." ${ }^{\text {" }}$ Even the most determined oppositional forces, it turned out, would likely wind up assimilated into the process of capitalist rationalization.

While Gramsci's view of ideological hegemony called attention to the general capacity of ruling elites to legitimate their rule through a mix of cultural traditions and ideological discourses, less well known was his essentially Weberian focus on Fordist control of the capitalist workplace. "Hegemony," Gramsci argued, "is born in the factory," noting that Fordism develops to the 
point where it "succeeds in making the whole life of the nation revolve around production," leaving the masses in a state of alienation and disempowerment - the focus here on "production" over "commodities," worth noting. He wrote: "In America rationalization has determined the need to elaborate a new type of man suited to the new type of work and productive process." That "new type of work" was typically suited to the "trained gorilla" of Fordist lore. ${ }^{90}$ In another twist of irony, Lenin had (in the years after the revolution) grown fascinated with Taylorism and its Soviet equivalent is known as "edinonachalia," or one-man management.

During this same period, Lukacs, in History and Class Consciousness, sought a different line of argumentation, looking to resuscitate Marx's fetishism of commodities through the concept of reification. Marx, it will be recalled, wrote in Capital that the commodity process intrinsic to capitalism had become fetishized as it transforms relations between humans, between humans and nature, into relations between objects. Capitalism degrades humans into the status of objects, while objects, as such, acquire human attributes. Insofar as bourgeois society matures into a system fully dependent on objects (and also objective laws), those engaged in the labor process lose any sense of self, their collective subjectivity and autonomy - and finally, their psychological capacity for revolutionary action. Capitalist development would forever be shrouded in ideological mystification. For Marx, as noted, no concept of transcendence is forthcoming - thus, no identifiable (subjective) exit from the existing order of things.

Lukacs provocatively took up this motif at a time when Gramsci and others were departing from the classic texts. It seems the Hungarian theorist wanted to deepen Marx's fixation on commodities - notably their mystifying consequences for the proletariat - while simultaneously looking for a way out, ultimately arriving at Leninism. At a time when capitalism was entering its rationalized (or state-capitalist) phase across Europe, Lukacs opted for the motif of "universallydominant commodities," where the "fate of the worker becomes the fate of capitalism as a whole." (Here Lukacs anticipates Karl Polanyi's 1944 classic The Great Transformation, where marketization permeates and defines capitalist society.) This familiar over-emphasis on markets, sometimes mythologized into "free markets" or "market fundamentalism," had been effectively countered by Weberian theory.). Writing in 1923, Lukacs argued that "for the first time in history the whole of society is subjected ... to a unified economic process, and the fate of every member of society is determined by unified laws". ${ }^{33}$ In other words, the proletariat was subjected to such crushing (apparently lawlike) ideological domination, that no exit seemed possible - that is until the heroic Leninist party comes to the rescue.

The Lukacsian view of class consciousness was, in fact, consistent with the overall pessimism of "Western Marxism": the failure of revolutionary opposition in Europe, the collapse of "permanent revolution," led to capitalist stabilization - or was it the reverse? Frankfurt School theorists would soon enough explore the hegemonic power of capitalist rationalization, which some (Friedrich Pollack most notably) believed was leading toward a new order, state-capitalism. Others, including Herbert Marcuse, saw incipient "totalitarian" tendencies visible in liberal-capitalism as early as the late 1920s. Assessing the (earlier) legacy of liberal capitalism, Marcuse could write: "This rough sketch of liberalist social theory has shown how many elements of the totalitarian view of the state are already present in it." Had conditions associated with the rise of fascism in Italy, Germany, and Spain already been theorized?

By the 1930s, others (Gramsci, Horkheimer, Adorno) had begun to detect the growing influence of the "culture industry" in the U.S., where the corporate media was on its ascendancy. None of these critics apparently saw the need to emphasize commodity fetishism, being more likely drawn to Weberian themes of capitalist rationalization and authoritarian state power. None, more significantly, were convinced that the proletarian revolution in the West was anything more than an outdated fantasy. With the onset of fascism, moreover, anti-system movements and parties across Europe were mostly crushed or simply vanished from the scene.

Among postwar texts that might be regarded as most closely approximating Lenin's turnof-the-century pessimism regarding proletarian self-activity, Marcuse's One-Dimensional Man 
surely deserves mention. (In contrast to Lukacs' Leninist exit strategy, however, Marcuse turned to "the great refusal" comprising a loose assemblage of "outsiders.") Turning to the growth of technological rationality in modern capitalism, Marcuse in 1964 could invoke the specter of a "totally-administered society" verging on "totalitarianism," where oppositional thinking becomes a grand illusion. Workers were now uniquely vulnerable to the corrosive effects of onedimensionality, their likelihood of developing class solidarity now rapidly disappearing. This was Gramsci's concept of ideological hegemony on steroids. In Marcuse's words: “Technical progress, extended to the whole system of domination and coordination, creates forms of life (and of power) which appear to reconcile the forces opposing the system and to defeat or refute all protest in the name of historical prospects of freedom from toil and domination . . . This containment of social change is perhaps the most singular achievement of advanced industrial society." 95 He added: "Today, domination perpetuates and extends itself not only through technology but as technology, and the latter provides the great legitimation of the expanding political power, which absorbs all spheres of culture." ${ }^{96}$ Could a more extreme view of ideological hegemony be found in Gramsci - or anyone else?

Marcuse's argument would seem to hold even more weight several decades later, with the rise of Silicon Valley, the oligopolistic high-tech sector, and surveillance society. While for years, it was fashionable to dwell on the growth of post-Fordism. Moreover, the widening repercussions of workplace rationalization (driven by the fast-food and retail sectors) were not to be overstated: crushing routinization of the labor process was rapidly expanding across low-wage sectors of the economy. In his classic The McDonaldization of Society, George Ritzer explored the systematic degradation of labor in American society, workers increasingly subjected to extremely repressive bureaucratic and technological controls. Labor techniques had become increasingly standardized, the workforce ever more homogeneous and interchangeable, jobs de-skilled in ways Taylor would have celebrated. The older variants of Fordism and Taylorism, severely ruinous to worker subjectivity, were being reintroduced beneath the façade of technological modernity. In Ritzer's words: "Fordism is alive and well in the modern world, although it has been transformed into McDonaldism. Furthermore, classic Fordism - for example, in the form of the assembly line - remains a significant presence in the American economy." 97 By the early twenty-first century, that supposedly outmoded presence had extended to nearly 25 percent of the workforce.

The waning of oppositional politics in the West cannot be fully grasped without reference to deepening trends associated with "mass society," increasingly visible after World War II. Such trends were first systematically explored by Frankfurt School critics, then further investigated during the 1950s by Mills in The Power Elite. For Mills, this phenomenon was organically connected to concentrated power at the summits of American society - in other words, the reverse side of capitalist rationalization. Mass society was becoming more homogeneous, conformist, and provincial behind a façade of "pluralism," "diversity," and democratic citizenship. Autonomous centers of opinion-formation had narrowed or disappeared, lost in the myriad forms of institutional and ideological control - a theme consistent with Marcuse's "one-dimensionality." As such, the system turned hostile toward expressions of class identity or class consciousness. As for "public opinion," it was now an assemblage of attitudes, beliefs, and myths routinely transmitted from the power elite to the general population. Viewed this way, public opinion had little validity of its own, being largely "realized within the prevailing institutions of power." 98 Nowhere was this more emphatically true than for postwar American society. How could class-based politics - indeed any anti-system opposition - possibly flourish in such a milieu?

For Mills, what might be described as "mass" or "public" had become associated with the system of domination Both individual or collective forms of subjectivity were negated to the extent "opinions become meaningless in the face of concentrated power." 99 Put differently: "In a mass society, the dominant type of communication is the formal media and the public becomes media markets." 100 The average person winds up atomized, separated, all too often submissive within the amorphous mass, thus incapable of democratic engagement. As elite power solidifies, it coexists with political impotence - hardly a recipe for proletarian self- 
activity or radical opposition. Mills concluded: "The structural trends of modern society and the manipulative character of its communications technique come to the point of coincidence in the mass society." 101 The distance traversed here from classical Marxism to the new era of social atomization could not be more extensive. By the early twenty-first century, moreover, the widening terrain of technological rationality - visible across the Internet, social media, and mobile communications - would profoundly widen this distance.

Now approaching the third decade of the new century, the shrinking influence of Marxist classics seems no longer debatable. No revolutionary working-class politics exists anywhere, and prospects for any setting appear remote. Such failure is hardly fortuitous but is rather endemic to modern capitalist development. As for labor, in most Western societies, its role -- both structural and numerical - is far less central than earlier Marxists could have assumed. What might be understood nowadays as an industrial proletariat amounts to no more than 15 percent of the workforce in most countries? Class relations, as such has grown far more complex, variegated, and fragmented, subverting hopes for working-class cultural or political solidarity. On this point, Ron Aronson, in After Marxism, writes: "Capitalism has long since ceased to be constructed by the labor of an alienated and impoverished majority of workers with 'radical chains,' who could also claim to be a universal class." 102

More challenging yet for Marxism is the failure to theorize ideological, political, and technological conditions that have transformed modern capitalism. A truncated view of capitalist rationalization stems in part from a different kind of commodity fetishism, fixed on a "market economy" that exists only as fiction kept alive by conservative propaganda. Although the commodity form remains and, in some ways, has broadened - visible in the form of consumer culture - its significance for "reification" (or hegemony) has weakened relative to other mechanisms of domination: state power, bureaucracy, technology, media culture. In the case of Saito, unfortunately, his Herculean efforts to resuscitate classical Marxism by endowing it with ecological cache are countered by failure to engage the dynamics of twenty-first-century capitalist rationalization.

By the 1960s, state-corporate globalization was producing new levels of environmental ruin, first documented by Rachel Carson. That was, not coincidentally, a time when ecological thought was gaining initial visibility, notable in the work of Carson, Barry Commoner, and Murray Bookchin. In the U.S., this breakthrough coincided with the rise of the new left, counterculture, and, by the 1970s, new social movements. At no point, however, did any ecological initiative converge with Marxist politics, while in Europe, those initiatives found a home in a few Green parties, just as both Socialist and Communist parties had become thoroughly deradicalized. Revisiting the familiar maxim that the natural world cannot be transformed without also transforming the human world, these new conditions meant that an ecological radicalism was desperately needed - years before climate change surfaced as a political imperative.

\section{From Marx to Ecosocialism}

It is now well more than a century since Marx and Engels last wrote anything for posterity. Much has changed across that expanse: capitalism still exists, in many ways stronger than ever, but has undergone transformations that nineteenth-century theorists could not have fully anticipated. Far removed from the era of classical political economy, capitalism has grown steadily more corporatized, more oligopolistic, more statist, more technological, more integrated, above all more globalized. (It is not enough to say that Marx and Engels were aware of such tendencies when, in fact, their work never systematically incorporated them.) While still beset with potentially explosive contradictions, the modern world system nonetheless appears integrated, less vulnerable to revolutionary challenge owing to its great integration, adaptability, and scope. Neither a more diversified and less proletarianized working class nor political forces once ideologically aligned with (a generally reformist) Marxism nowadays offer a viable threat 
to elite power. The yawning gulf separating classical theory (liberal or Marxist) from modern capitalist reality is hardly to be blamed on the writers; they were, like other mortal intellectuals, working within certain historical parameters.

As the present ecological crisis worsens by the day, its reversal calls for a reckoning with global capitalism before it is too late to save planetary life as we know it. Climate change and related problems, resulting from ceaseless economic growth, urbanization, fossil-fuel driven warming, and resource wars bring humanity ever closer to imminent catastrophe. The current threat far transcends anything that might be associated with "metabolic rift." over the decades. The path to theoretical clarity and political strategy will now have to follow a different course than anything derived from the Marxist classics. It is one thing to argue for eliminating "private property" or "commodity production" in favor of a socialized economy, still, another to strategically confront the largest power structure ever known, one embedded in sprawling fortresses of corporate, state, and military interests. It is one thing to imagine a "proletarian revolution," yet another to forge a complex, shifting, multiclass bloc of oppositional forces capable of taking on world capitalism. It is one thing to anticipate a natural upsurge of "revolutionary consciousness" among workers, yet another to subvert expanding forms of ideological hegemony, bureaucratic hierarchy, and technological control precisely designed to block such consciousness. It is one thing to fantasize about an epochal "reunification" of humans and nature, yet another to begin transforming a globalized regime that spends trillions of dollars to protect its wealth and power while violently perpetuating its "domination of nature."

At this juncture, the old Marxist assumption of imputed revolutionary consciousness falls dramatically short of the new political challenges. In their provocative book Climate Leviathan, Geoff Mann and Joel Wainwright call for a radical departure from political normalcy, even as few mass counter-forces are presently visible. They write: "On political and existential grounds ... the left needs a strategy - a political theory, one might say - for how to think about the future." "103 One problem is that ideological legacies inherited from the past appear exhausted: Communism, social democracy, liberalism, anarchism. As for liberalism, it now serves mainly as legitimating belief-system for capitalist power, while social democracy has never systematically (or radically) addressed the ecological challenge. Communism, such as it is, remains far too closely identified with extreme authoritarian power grown increasingly bureaucratic and conservative to be taken seriously as an alternative.

Turning to this predicament, Mann and Wainwright argue for what might be considered a (somewhat moderated) variant of Jacobinism - an outcome they believe even now inheres in what they call "planetary sovereignty," or "world government," a system with enough power to make binding, global, life-and-death decisions. They note that the world system is well along a path to Climate Leviathan, "because the further consolidation and expansion of extant power structures would seem to be the only structures of scale, scope, and authority even close to adequate to the challenge of climate change." 104 Precisely how this Leviathan might be taken to the next level, however, is never clearly indicated. The "planetary sovereignty" Mann and Wainwright have in mind would ideally intersect with an expansive green Keynesianism, or worldwide Green New Deal. Waiting patiently for history (or systemic contradictions) to eventually generate political solutions adequate to the threat facing humanity is futile, no more realistic than expectations of the proletarian revolution. If no radicalized mass constituency is likely to emerge through conventional electoral activity, what then? Could such a departure suggest it is time to revisit, in modified form, the creative Jacobinism of Lenin and Gramsci? 


\section{Endnotes}

1. Michael Lowy, Ecosocialism (Chicago: Haymarket Books, 2015), ix.

2. Lowy, 79.

3. David Wallace-Wells, The Uninhabitable Earth (New York: Tom Duggan Books, 2019), 4.

4. Wallace-Wells, 14-15.

5. Andreas Malm, Fossil Capital (London: Verso, 2016), 10.

6. Kohei Saito, Karl Marx’s Ecosocialism (New York: Monthly Review, 2017), 9.

7. Lowy, Ecosocialism, 4.

8. Saito, Karl Marx, 17.

9. Ibid.

10. Saito, 258.

11. Saito, 263.

12. Saito, 133.

13. Saito, 119.

14. Saito, 99.

15. Saito, 20.

16. Saito, 263.

17. Saito, 217.

18. See John Bellamy Foster, Marx’s Ecology (New York: Monthly Review Press, 2000). Also: Paul Burkett, Marx and Nature: A Red and Green Perspective (New York: Monthly Review Press, 1999).

19. Fred Magdoff and Chris Williams, Creating an Ecological Society (New York: Monthly Review Press, 2017).

20. Foster, 139.
21. Foster, 136.

22. Foster, viii.

23. Saito, Karl Marx, 257.

24. Saito, 20.

25. Saito, 217.

26. Karl Marx, "Economic and Philosophical Manuscripts of 1844", in Robert C. Tucker, ed., The Marx-Engels Reader (New York: W.W. Norton, 1972), 75.

27. Marx, 76.

28. Karl Marx, "The Manifesto of the Communist Party", in Tucker, 477.

29. Marx, 490.

30. Karl Marx, "The Grundrisse”, in Tucker, 285.

31. Karl Marx, "Capital, Volume One", in Tucker, 347. Italics in original.

32. Karl Marx, "Capital, Volume Three", in Tucker, 441.

33. Karl Marx, "Critique of the Gotha Program”, in Tucker, 526.

34. Friedrich Engels, "Socialism: Utopian and Scientific", in Tucker, 708.

35. Engels, 715.

36. Ibid.

37. Engels, 717.

38. Ibid. Italics in original.

39. Saito, Karl Marx, 257.

40. Saito, 258. 
41. Saito, 259.

42. On the scientific materialism that shaped development of the Second International up to World War I, see Leszek Kolakowski, Main Currents of Marxism - 2 (New York: Oxford University Press, 1981), chs. 1, 2.

43. See Paul W. Taylor, “The Ethics of Respect for Nature", in Michael E. Zimmerman, et. al., eds., Environmental Philosophy (New York: Prentice-Hall, 1993).

44. Saito, Karl Marx, 99.

45. Saito, 259.

46. Karl Marx, "Economic and Philosophical Manuscripts of 1844", in Tucker, 89.

47. Marx, 76.

48. Max Horkheimer and Theodor W. Adorno, Dialectic of Enlightenment (New York: Continuum, 1995), xii-xiv.

49. Horkheimer and Adorno, 245.

50. Ibid.

51. Horkheimer and Adorno, 249.

52. See John Santonmatsu, "Introduction", in Sanbonmatsu, ed., Critical Theory and Animal Liberation (Lanham, Md.: Rowman and Littlefield, 2011), 12.

53. Sanbonmatsu, 21.

54. On the indisputable contribution of meat consumption to the modern ecological crisis, see Lester R. Brown Full Planet, Empty Plates (New York: W. W. Norton, 2012), chs. 3-8.

55. Sanbonmatsu, in Critical Theory, 31.

56. Richard Oppenlander, Comfortably Unaware (New York: Beaufort Books, 2012), 11,81 .

57. Alejandro Colas, et. al. Food, Politics, and Society (Berkeley: University of California
Press, 2018), 83.

58. Brown, Full Planet, 141.

59. See Ted Benton, Natural Relations

(London: Verso, 1993), 45.

60. Magdoff and Williams, Ecological Society, 257-58.

61. Victoria Johnson, "Everyday Rituals of the Master Race", in Sanbonmatsu, Critical Theory, 205-07.

62. For an excellent discussion of Stalin's theoretical shifts and turns, see T. H. Rigby, ed., Stalin (New York: Prentice-Hall, 1966).

63. Herbert Marcuse, Soviet Marxism (New York: Vintage Books, 1956), 122.

64. James William Gibson, The Perfect War (New York: Atlantic Monthly, 1986), 462.

65. Max Horkheimer, "Critical and Traditional Theory", in Critical Theory: Selected Essays (New York: Continuum, 1972), 216.

66. Sheldon Wolin, "The Epic Tradition of Political Theory", in Nicholas Xenos, ed., Sheldon S. Wolin: Fugitive Democracy and Other Essays (Princeton, N.J.: Princeton University Press, 2016), 108.

67. Wolin, "Political Theory as a Vocation", in Fugitive Democracy, 23.

68. Antonio Gramsci, "The Study of Philosophy", in Quintin Hoare and Geoffrey Nowell Smith, ed., Selections from the Prison Notebooks of Antonio Gramsci (New York: International Publishers, 1971), 345.

69. Antonio Gramsci, "Problems of Marxism", in SPN, 430.

70. Gramsci, 465.

71. Gramsci, 436.

72. Antonio Gramsci, “The Revolution Against Capital”, in Quintin Hoare, ed., Antonio 
Gramsci: Selections from Political Writings (New York: International Publishers, 1977), 34.

73. Antonio Gramsci, "The Modern Prince", in SPN, 125-36.

74. Antonio Gramsci, "The Russian Utopia”, in Selections, 48.

75. Antonio Gramsci, "The Conquest of the State", in Selections, 76.

76. Georg Lukacs, Lenin (Cambridge, MA.: MIT Press, 1971), 70.

77. Lukacs, 31.

78. E. H. Carr, The October Revolution (New York: Vintage Books, 1969), 164.

79. V. I. Lenin, "Left Wing Communism: An Infantile Disorder", in Robert C. Tucker, ed., The Lenin Anthology (New York: W. W. Norton, 1975), 611.

80. V. I. Lenin, The Proletarian Revolution and the Renegade Kautsky (New York: International Publishers, 1934), 21.

81. See Eric Wolf, Peasant Wars of the Twentieth Century (New York: Harper and Row, 1968).

82. See Paolo Spriano, The Occupation of the Factories (London: Pluto Press, 1964), ch. 10.

83. Antonio Gramsci, "The Revolution Against Capital”, in Selections, 36.

84. Antonio Gramsci, "State and Civil Society", in $\underline{\text { SPN, }}$ 324-42.

85. Antonio Gramsci, "Americanism and Fordism", in $\underline{\text { SPN, }}$ 277-319.

86. V. I. Lenin, "What is to be Done?", in Lenin Anthology, 29-30.

87. Very little of Machajski's work, mostly completed the first decade of the twentieth century, has been translated into English. It did, however, lay the groundwork for later "new-class" theories. See the discussion in Richard Gombin, The Radical Tradition (London: Methuen and Co., 1978), 65-69.

88. See Robert Michels, Political Parties (New Brunswick, N.J.: Transaction Publishers, 1999), 333.

89. Michels, 354.

90. Antonio Gramsci, "Americanism and Fordism", in $\underline{\text { SPN, }}$ 285-87.

91. Georg Lukacs, History and Class Consciousness (Cambridge, MA.: MIT Press, 1968), 90-91.

92. Karl Polanyi, The Great Transformation (Boston: Beacon Press, 1944).

93. Lukacs, History, 92.

94. Herbert Marcuse, Negations (Boston: Beacon Press, 1968), 8.

95. Herbert Marcuse, One Dimensional Man (Boston: Beacon Press, 1964), xii.

96. Marcuse, 158.

97. George Ritzer, The McDonaldization of Society (Thousand Oaks, CA.: Pine Forge Press, 2000), 183.

98. C. Wright Mills, The Power Elite (New York: Oxford University Press, 1956), 299.

99. Mills, 303-04.

100. Mills, 304.

101. Mills, 320.

102. See Ronald Aronson, After Marxism (New York: Guilford Press, 1995), 58.

103. Geoff Mann and Joel Wainwright, Climate Leviathan (London: Verso, 2018), 130.

104. Mann and Wainwright, 173. 